\title{
Project management offices in Russian engineering companies
}

\author{
Natalya Novikova ${ }^{1, a}$, Nikolay Barchan ${ }^{1}$, Elena Vikhodtseva ${ }^{2}$, Maria Guseva ${ }^{2}$ and Sergei Nikitin ${ }^{2}$ \\ ${ }^{1}$ Moscow Technological Institute, 119334 Moscow, Russia \\ ${ }^{2}$ State University of Management, 109542 Moscow, Russia
}

\begin{abstract}
Project management offices (or PMOs) are becoming a very well known concept and widely used organizational unit which is organized to support and develop project management systems and methodologies in companies in various sectors of economy. PMOs are being organized in more and more Russian engineering companies. However, PMOs have different forms and functions in different organizational context. It is very useful for theory and practice to analyze the real practice and define which characteristics and forms of PMOs are more accepted. The research presented in the article shows that PMOs are very popular among Russian engineering companies and the trends in their development are in line with the trends in other countries and industries.
\end{abstract}

\section{Introduction}

Over the last decade, engineering companies in Russia and worldwide have been facing new challenges related to increased competition, accelerated pace of innovations, shortened lifecycles of products, general economic volatility. As a response to these new challenges engineering companies are adopting new managerial frameworks and developing new organizational forms in order to implement more flexible and responsive project management approaches. One of the relatively new project-based organizational forms implemented in some engineering companies is the project management office or PMO. The theoretical aspects of PMOs have been extensively covered in the professional literature $[1 ; 2]$. But the empirical research on functions, forms and efficiency of PMOs in engineering companies is not sufficient in the current literature stream.

\section{Forms and functions of PMO}

Recent studies revealed extreme variety in forms and functions of PMOs [3]. Furthermore, some researchers discovered the high level of instability of PMOs which means that in the same organization PMO can change significantly its form, functions, level of subordination, number and scope of projects under control during short period of time [4]. Hobbs, Aubry and Thuillier (2008) explain these specificities of PMOs in the way that PMOs should be considered as constant organizational innovation that are still in the process of experimentation and search for the best practices [5].

Several attempts to produce the typology of PMOs have been made by several researchers. For instance, Kerzner (2003) identified such types as 'Client PMO',
'Functinal PMO' and 'Corporate PMO' [6]. Crawford (2011) distinguished between 'Control project office', 'Business unit project office', 'Strategic project office'. [1]. Englund, Graham and Dinsmore (2003) proposed the typology of PMOs which included 'Project support office', 'Project management centre of excellence' and 'Program management office' [2]. Kendall and Rollins (2003) identified four different models of PMO: 'Project repository model', 'Coach model', 'Enterprise model' and 'Delivery now model' [7]. There are other typologies of PMOs, but according to the convincing analysis of Dai and Wells (2004) all existing typologies are very vague, do not correspond to each other and do not provide clear basis for classification [8]. They suggest that instead of identification of different types it is more practically usefull and scientifically rigorous to use four dimensions along which PMOs differ. These dimensions are the place of PMO in the organizational structure of a company (level of management), the scope of control (how many projects are under control of PMO), the number of fulltime employees in PMO, the number and the nature of functions performed by PMO.

The problem of PMO functions needs more attention because this dimenstion is the most powerful source of variety of PMOs in companies. Again, as in the case with the types of $\mathrm{PMO}$, different authors propose different lists of PMO functions $[4 ; 8-11]$. After the discussion of different lists of PMO functions with the sample of respondents the list elaborated by Dai and Wells (2004) [8] was selected as the most comprehensible and convenient for the purposes of this research. Another advantage of the list suggested by Dai and Wells is that it was used in several empirical researches of PMO forms and functions. This list includes the following PMO functions:

\footnotetext{
a Corresponding author: s_titov@mti.edu.ru
} 
- Development, deployment and support of project management standards and methods;

- Trainings and education in project management area;

- Management of documents and archives, knowledge management;

- Administrative and technical support and help for project managers;

- Consulting and methodological support of project managers;

- Recruiting and talent development in project management area;

- Monitoring and audit of projects;

- Program and portfolio management;

- Financial supervision and budgeting.

\section{Research methodology}

This research was organized as a survey with the participation of the practicing engineers from Russian engineering companies.

Russian National Association of Engineers was approached and asked for the permission to send the invitation to members of the association to participate in the survey about PMOs in their companies. From 175 members positive responses were received and to these people questionnaires were sent. Correctly and unambiguously filled forms were received from 115 engineers.

The respondents had on average 12 years of work experience and about 5 years of the professional participation in project management activities in their companies. $72 \%$ of respondents worked for engineering companies and the rest worked in engineering departments of companies without engineering specialization.

The respondents were asked about their knowledge about PMOs and the existence of PMOs in their companies. Those respondents who reported that PMO were organized in their companies were asked several questions about the forms and functions of their PMOs.

\section{Research findings}

The answers of the respondents showed that from 115 participants only 17 respondents did not hear about PMOs and did not have any knowledge of them. Another 21 respondents said that they heard of PMOs, but had very vague knowledge of them and never saw them functioning in real practice. Yet another 33 people reported that they had good knowledge of PMOs, their functions and forms, but their companies did not have PMOs. Finally, 44 engineers (from different companies) said that their companies organized PMOs and still have them as functioning organizational entity.

From 44 PMOs in engineering companies 17 (38,6\%) were established at the top level of management with a manager of PMO reported directly to CEO. 24 PMOs $(54,5 \%)$ were organized at the middle managerial level with the subordination to one of the directors of departments. The rest of PMOs (3, or 6,9\%) were introduced at the low level of the organizational structure and considered as more technical rather than managerial.

Table 1. Distribution of respondents according to their knowledge of PMO and practical establishment of PMOs in their companies.

\begin{tabular}{|l|c|c|}
\hline Attitude towards PMO & $\begin{array}{l}\text { Number of } \\
\text { respondents }\end{array}$ & $\begin{array}{l}\text { Number of } \\
\text { respondents } \\
\text { (in \%) }\end{array}$ \\
\hline $\begin{array}{l}\text { Lack of knowledge about } \\
\text { PMO }\end{array}$ & 17 & $14,8 \%$ \\
\hline $\begin{array}{l}\text { Limited/ vague knowledge } \\
\text { about PMO }\end{array}$ & 21 & $18,3 \%$ \\
\hline $\begin{array}{l}\text { Good knowledge about } \\
\text { PMO without } \\
\text { implementation }\end{array}$ & 33 & $28,7 \%$ \\
\hline $\begin{array}{l}\text { Practical knowledge about } \\
\text { PMO with implementation } \\
\text { in companies }\end{array}$ & 44 & $38,3 \%$ \\
\hline Total & 115 & $100 \%$ \\
\hline
\end{tabular}

According to the last group of respondents, the majority of PMOs in Russian engineering companies were organized in the 2010s (see Figure 1).

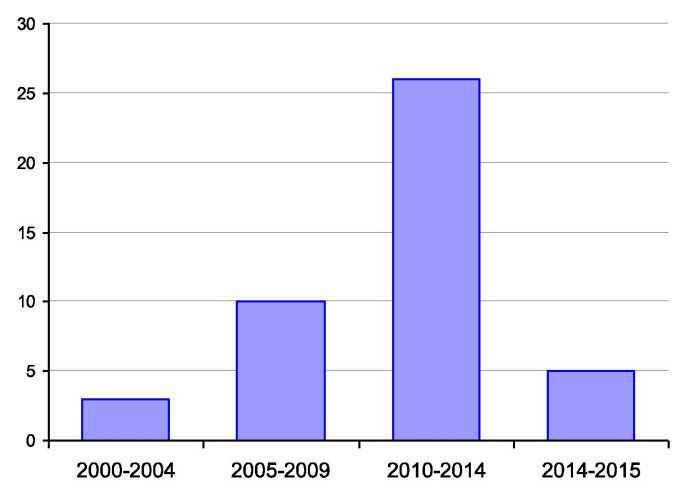

Figure 1. The number of PMOs established in Russian engineering companies

None of the PMOs controlled from 90 to $100 \%$ of the company's projects. 12 PMOs supervised from 75 to $89 \%$ companies' projects. 19 PMOs had from 50 to $74 \%$ of projects under their control. 8 PMOs controlled from 25 to $49 \%$ of projects and other 3 PMOs did not have projects under their supervision.

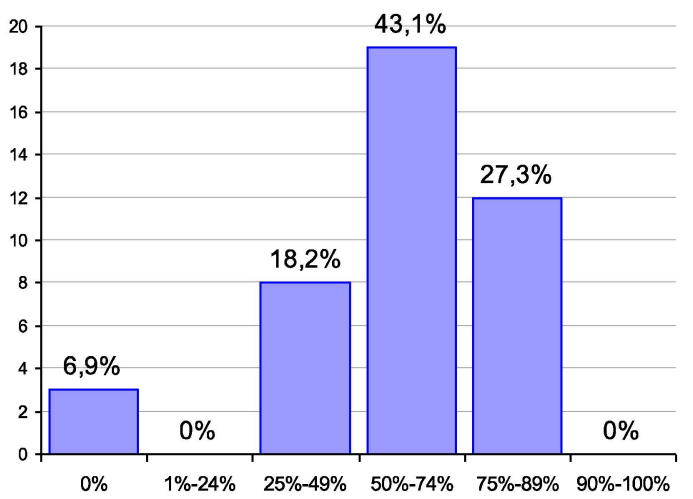

Figure 2. Scope of control of PMOs (in \% of company's projects under control) 
From all 44 PMOs 14 had the number of staff less than 5 employees, 18 PMOs had from 6 to 10 people of permanent staff and 12 PMOs had the staff with 11 or more employees.

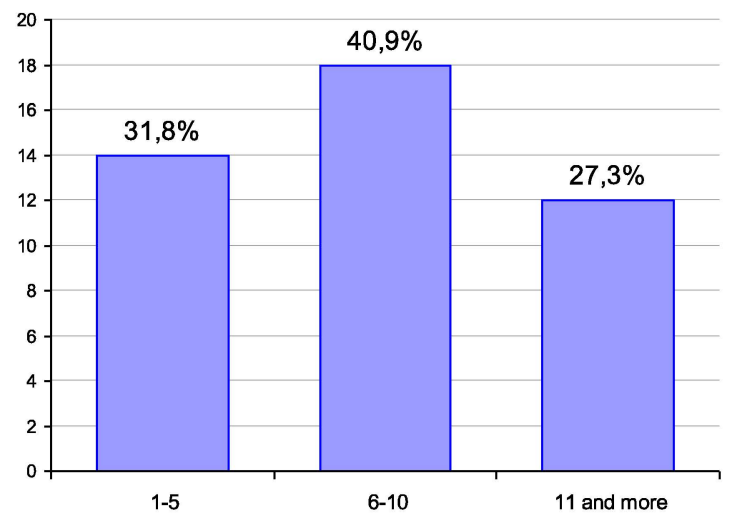

Figure 3. The full-time staff of PMOs established in Russian engineering companies

The respondents which reported the existence of PMO in their companies were asked about the functions that PMOs perform. The list of PMO functions defined above in the article was used in the survey questionnaire. The respondents were able to choose any number of PMO functions from the list. The distribution of the positive answers of respondents across PMO functions is presented in Table 2.

\section{Discussion on research results}

One of the most interesting findings of the research is the discovery of the fact that PMO in the community of Russian engineering community is a well known concept. The overwhelming majority of the respondents $(85,2 \%)$ has limited or good knowledge of PMO, its organizational mission and functions. The proportion of engineering companies which already established PMO is rather high. Dai and Wells (2004) [8] analyzed how often PMO is established and used in different companies across various sectors of economy and found that at the highest level PMOs are used in software, communication and hardware companies. But even in these companies the portion of companies with PMO is about $10-15 \%$ which is much lower than discovered level in Russian engineering companies. In the research of Dai and Wells (2004) the percentage of engineering companies with PMOs was only $5 \%$. Though that can be explained by the fact that the research of Dai and Wells was made in 2004, and the popularity of PMO has been increasing since that year.

In terms of the forms of PMO the trends in Russian engineering companies is more or less similar to the global trends. The majority of PMOs are established at the middle managerial level $(54,2 \%)$ with the rather wide scope of control (70,4\% of PMOs have more than $50 \%$ companies' projects under supervision). The bulk of PMOs has the full-time staff 10 people and less. According to the research by Hobbs and Aubry (2008) which cover more than 200 PMOs in different countries and sectors of economy, the companies tend to organize PMOs at the middle level of authority, with middle-tohigh scope of control and with the full-time staff from 5 to 15 employees [12].

Table 2. Performance of PMO functions in Russian engineering companies.

\begin{tabular}{|l|c|c|}
\hline \multicolumn{1}{|c|}{ PMO function } & $\begin{array}{c}\text { Number of } \\
\text { respondents } \\
\text { which } \\
\text { reported } \\
\text { about } \\
\text { performance } \\
\text { of the PMO } \\
\text { function in } \\
\text { their } \\
\text { companies }\end{array}$ & $\begin{array}{c}\text { Number of } \\
\text { respondents } \\
\text { which } \\
\text { reported } \\
\text { about } \\
\text { performance } \\
\text { of the PMO } \\
\text { function in } \\
\text { their } \\
\text { companies (in } \\
\text { \%) }\end{array}$ \\
\hline $\begin{array}{l}\text { Development, } \\
\text { deployment and support } \\
\text { of project management } \\
\text { standards and methods }\end{array}$ & 110 & $95,7 \%$ \\
\hline $\begin{array}{l}\text { Trainings and education } \\
\text { in project management } \\
\text { area }\end{array}$ & 85 & $73,9 \%$ \\
\hline $\begin{array}{l}\text { Management of } \\
\text { documents and archives, } \\
\text { knowledge management }\end{array}$ & 54 & $47,0 \%$ \\
\hline $\begin{array}{l}\text { Administrative and } \\
\text { technical support and help } \\
\text { for project managers }\end{array}$ & 52 & $45,2 \%$ \\
\hline $\begin{array}{l}\text { Consulting and } \\
\text { methodological support of } \\
\text { project managers }\end{array}$ & 44 & $38,3 \%$ \\
\hline $\begin{array}{l}\text { Recruiting and talent } \\
\text { development in project } \\
\text { management area }\end{array}$ & 23 & $20,0 \%$ \\
\hline $\begin{array}{l}\text { Monitoring and audit of } \\
\text { projects }\end{array}$ & 19 & $16,5 \%$ \\
\hline $\begin{array}{l}\text { Program and portfolio } \\
\text { management }\end{array}$ & 4 & $1,5 \%$ \\
\hline $\begin{array}{l}\text { Financial supervision and } \\
\text { budgeting }\end{array}$ & 2 & \begin{tabular}{c} 
\\
\hline Total
\end{tabular} \\
\hline
\end{tabular}

It is interesting to compare the PMO functions in Russian engineering companies with the functions of other analyzed PMOs. Dai and Wells (2004) investigated the popularity of different functions in about 100 PMOs in different companies. Due to the fact that in this research we used the same list of PMO function it is possible to compare the results. The comparison of the results of two studies is presented in Figure 4.

From Figure 4 we see that such functions as 'Development, deployment and support of PM standards and methods', 'Trainings and education in PM area', 'Recruiting and talent development in PM area', 'Program and portfolio management' and 'Financial supervision and budgeting' are performed in Russian engineering companies almost as frequently as in other companies analyzed by Dai and Wells (2004) [8]. 


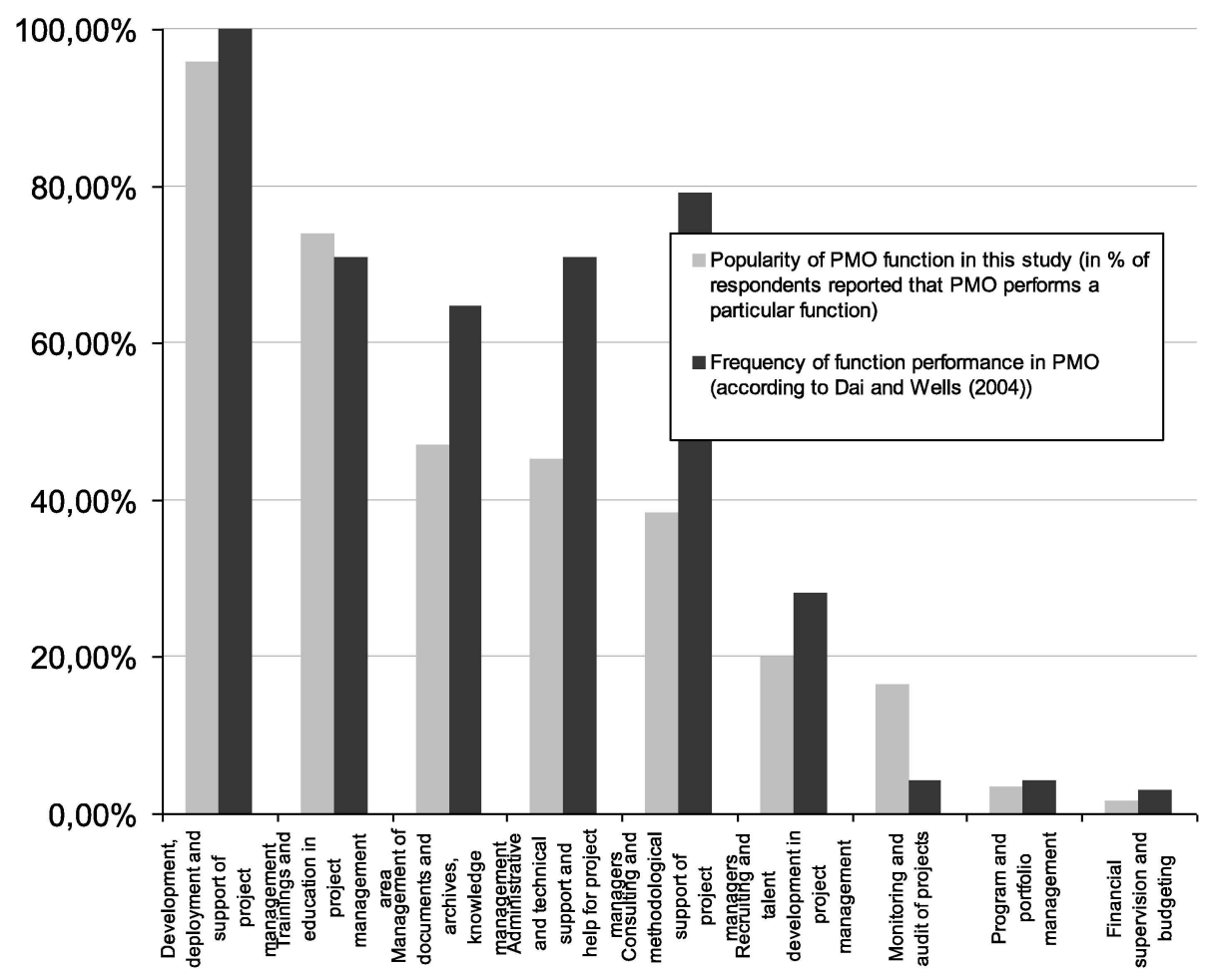

Figure 4. The full-time staff of PMOs established in Russian engineering companies

Functions 'Management of documents, archives and knowledge management', 'Administrative and technical support for PMs', 'Consulting and methodological support of PMs' are performed in Russian engineering companies notable less frequently than in the sample research by Dai and Wells. 'Monitoring and audit of projects' is a more popular function among Russian engineering companies than in other companies. However, admitting all the identified differences, the general patterns of the frequencies of PMO functions are very similar in both studies.

\section{Conclusion}

It is worth emphasizing that the popularity of PMO among Russian engineering companies is very high by world standards. PMO can be considered as a widely excepted organizational unit which officially established in engineering companies in order to support and develop corporate project management systems and methodologies.

The discovered variety of forms and functions of PMOs in Russian engineering companies are similar to those that were analyzed by other researchers in other companies in the world.

\section{References}

1. J.K. Crawford, The Strategic Project Office (Marcel Dekker, 2002)
2. R.L. Englund, R.J. Graham and P.C. Dinsmore, Creating the Project Office: A Manager's Guide to Leading Organizational Change (Jossey-Bass, 2003)

3. G.M. Hill, Inform Syst Manage, 21, 45 (2004)

4. B. Hobbs and M. Aubry, PMJ, 38, 74 (2007)

5. B. Hobbs, M. Aubry and D. Thuillier, Int J Proj Manage, 26, 547 (2008)

6. H. Kerzner, PMJ, 34, 13 (2003)

7. G.I. Kendall, and S.C. Rollins, Advanced Project Portfolio Management and the PMO: Multiplying ROI at Warp Speed (J.Ross Publishing, 2003)

8. X.C. Dai and W.G. Wells, Int J Proj Manage, 22, 523 (2004)

9. H. Kerzner, Project Management Best Practices: Achieving Global Excellence (Wiley, 2006)

10. S. Pellegrinelli and L. Garagna, Int J Proj Manage, 27, 649 (2009)

11. K.C. Desouza and J.R. Evaristo, Int J Inform Manage, 26, 414 (2006)

12. B. Hobbs and M. Aubry, PMJ, 39, 69 (2008) 